\title{
Assessment of Fertilizer Policy, Farmers' Perceptions and Implications for Future Agricultural Development in Nepal
}

\author{
Nani Raut ${ }^{1} \&$ Bishal K. Sitaula ${ }^{1}$ \\ ${ }^{1}$ Department of International Environment and Development Studies (Noragric), Agricultural University of \\ Norway, Norway \\ Correspondence: Nani Raut, Department of International Environment and Development Studies (Noragric), \\ Agricultural University of Norway, Norway. Tel: 47-6496-5340. E-mail: rautnani7@gmail.com
}

Received: April 13, 2012 Accepted: May 28, 2012 Online Published: July 20, 2012

doi:10.5539/sar.v1n2p188

URL: http://dx.doi.org/10.5539/sar.v1n2p188

\begin{abstract}
This paper assesses the origins of and changes to fertilizer policy in Nepal over a period of time. It assesses farmers' awareness of the recent changes to the subsidy policy and examines their perceptions of the extension services. This paper looks at the environmental implications of the concentrated application of chemical fertilizer, particularly as far as food security is concerned. Questionnaire surveys, group discussions, a workshop, soil analyses and archival materials were used to collect data for this study. Changes in fertilizer policy have occurred in four different phases: (i) without subsidy; (ii) with subsidy; (iii) with deregulation of fertilizer trade; and (iv) the current phase of subsidies for fertilizer. However, timely and effective fertilizer distribution by the government has always been a problem. Only few farmers (12\%) know about recent changes in the fertilizer policy; most of them (44\%) were satisfied with the new subsidy scheme. Valid proof of land ownership is a requirement for qualifying for subsidized fertilizer, and this makes it difficult for some small farmers who are tenant. The soil analysis indicated a significant decrease in the soil $\mathrm{pH}$ as a result of intensified agriculture. One reason is due to the intensive use of chemical fertilizers and the declining use of farmyard manure. The ineffectiveness of the extension services also influences farmers' use of fertilizer as they are not aware of which fertilizer and how much to use. The use of fertilizer may increase yields in the short term, but in the longer term, it may worsen the food insecurity in the country.
\end{abstract}

Key words: fertilizer subsidy, intensified agriculture, extension service, soil $\mathrm{pH}$

\section{Introduction}

The increasing global population and economic growth are the major forces driving the demand for increased food production, crop production and fertilizer use (Foresight, 2011; FAO, 2011). Boserup (1965) argues that the increasing population pressure means that we must find ways to increase the supply of food through the increased use of machinery, fertilizer, etc. To cope with the increased population we need to make use of new technology and shift from traditional agricultural practices to intensified farming systems. The role of new technologies and innovations in addressing food security challenges is widely recognized. The Green Revolution was an innovation introduced in many countries in Asia during the 1960s in order to attain food self-sufficiency. It was supported by subsidized credit and fertilizer, and the development of irrigation. The subsidy and credit programs resulted in increased use of fertilizer in Asia (Gulati \& Sharma, 1995; Murgai et al., 2001) and other parts of the world (Matsumoto \& Yamano, 2011).

With an estimated $31 \%$ of the population living below the national poverty line, poverty alleviation is the biggest long-term development challenge for the government (CIP, 2010). Currently about $80 \%$ of Nepal's population lives in rural areas and agriculture is their primary source of livelihood (Samriddhi, 2011). About $66 \%$ of the total population of Nepal is dependent on agriculture (MoAC, 2005), and agriculture contributes to more than one-third of the country's GDP. In this context, the intensification of agriculture has been seen as one of the options in the country's development agenda (Samriddhi, 2011; Dahal et al., 2009).

Food insecurity is high, with $61 \%$ of farmers lacking sufficiency in food (NARC, 2010). The food availability situation is getting worse in Nepal. The production of cereals has been increasing at a rate of $2 \%$ per annum, which is below the population growth of $2.25 \%$ in Nepal (CIP, 2010). Comparing the three ecological regions of Nepal in 2008/2009, the hill and mountain regions were in a food-deficit situation whereas the terai (a low-lying 
plain area) was in a food-surplus situation (CIP, 2010). The food-deficit situation is mainly due to food unavailability and constraints in food access due to the financial constraints experienced by poor households, and the physical constraints associated with poor infrastructure, such as lack of adequate roads or markets.

There is an increased realization of the food insecurity situation by government policy makers. In the last few decades, the government has prioritized the development of agriculture. The government endorsed a twenty-year Agriculture Perspective Plan (APP) in 1995, which has been implemented since 1997. This created two lines of defence for providing food security. The first was to ensure that adequate quantities of food were available, and the second was to ensure adequate purchasing power for food. The APP set per capita targets for food production of $245 \mathrm{~kg}$ for the mountain region, $380 \mathrm{~kg}$ for the hill region, and $482 \mathrm{~kg}$ for the terai region, to be met by 2014/15. It has identified chemical fertilizer as the engine of agricultural growth. Fertilizer is expected to contribute $64 \%$ to $75 \%$ of the total agricultural growth target of the APP. It envisions an increase in fertilizer usage from $31 \mathrm{~kg}$ nutrient/ha in the base year 1995 to $131 \mathrm{~kg}$ nutrient/ha by 2017 (APP, 1995). This has resulted in a shift from the traditional type of cultivation to intensified agriculture in areas close to urban centres with access to roads, markets and inputs (Dahal et al., 2009; Brown \& Shrestha, 2000; Brown \& Kennedy, 2005). The increasing number of crops per annum, the adoption of higher yielding varieties, and farmers' concern about the insufficient sources of Farm Yard Manure (FYM) to meet the necessities for household crop production are all leading to an increased use of chemical fertilizers. However, supplying enough fertilizer to the farmers has always been a challenge for the government of Nepal. Despite the targets set by the APP, agriculture production figures have remained stagnant. This has been attributed to institutional weakness which has led to a failure to prioritize fertilizer supply and to the poor delivery of inputs, etc. This is in spite of the APP planning for efficient fertilizer supply with the assistance of a variety of institutions such as Agricultural Inputs Corporation (AIC), private sectors, Nepal Agricultural Research Council (NARC), and cooperatives (Samriddhi, 2011). One way of building institutional strength is through collaboration and partnership between the public and private sectors. Public-private partnerships are defined as any collaborative effort between the public and private sectors in which each sector contributes to the planning, resources and activities needed to attain a mutual objective. These are ways of enhancing extension services, and improving production and agricultural technologies which would help to ensure that policy targets are met (Rosenau, 2000).

The country has often changed its fertilizer policies in a bid to ensure an uninterrupted supply throughout the country and to accelerate growth in food production through the intensive use of chemical fertilizers (Shrestha, 2010). Following the deregulation of the fertilizer sector in 1999, there have been concerns that the supply of chemical fertilizers has not improved. Recently, in 2009, the government re-introduced the subsidy on chemical fertilizers. Given this, a central question to be addressed here is: In what ways can the fertilizer policy contribute to the present and future demand for food production in the country? In this context, it is important to examine the changing policies with regard to fertilizer and the institutional structures related to the supply of fertilizer.

There have been independent studies on the use of fertilizer in Nepal (ACI, 2003), the constraints in the supply of fertilizer (Thapa, 2006), and on the development of fertilizer policy (Shrestha, 2010). However, these studies do not address the effects of fertilizer policy changes on farmers' actions and the levels of food security. The aim of this study is thus to evaluate the impact of the Green Revolution adopted in other Asian countries on the use of chemical fertilizer in Nepal, the development of extension services and the farmers' responses to these initiatives. The specific objectives are

(1) to determine the origins of and changes to fertilizer policy over a period of time;

(2) to assess the effectiveness of extension services and farmers' perceptions of these services;

(3) to analyse the environmental implications of the increased application of chemical fertilizer on the soil; and

(4) to study farmers' awareness of the current subsidy policy.

These aims were integrated in order to assess the overall implications for food security in Nepal. This study could provide relevant lessons and feedback for policy makers and extension officers, and could assist in the development of appropriate policy options at the national level.

\section{Methods}

The study is based on a household surveys, group discussions, a workshop, a review of the relevant literatures and soil analysis. A household survey was conducted in the Ansikhola sub-watershed located in the Kavre district of central Nepal. The watershed comprises of a total of 12 wards from four Village Development Committees (VDC), namely Devitar (one ward), Anaikot (three wards), Nayagaon (six wards) and Mahadevsthan (two wards), making a total of 1038 households. A random sampling procedure was followed for 
the household survey. From the 1038 households in the watershed, a sample of 310 households (representing $30 \%$ ) was randomly selected. A structured questionnaire that comprised of both closed- and open-ended questions was prepared and pre-tested with respondents from the Chakhola watershed (a watershed with similar biophysical and socio-economic conditions to Ansikhola watershed) to ensure suitability. The survey was conducted between April and July 2009 by two trained enumerators. The heads of selected households were interviewed using a structured questionnaire. Detailed information was obtained through the questionnaire survey on the following matters:

(1) the status of institutional support services;

(2) the farmers' views on fertilizer subsidies;

(3) the farmers' involvement in training (and the type of training related to agricultural intensification);

(4) the farmers as recipients of loans for agricultural activities from governmental and non-governmental organizations; and

(5) the farmers' levels of satisfaction with the performance of the extension services and the training offered.

In order to obtain information on the farmers' levels of satisfaction with the fertilizer policy, the extension services and the training offered, the questionnaires made use of a five-point Likert scale, ranging from one, highly satisfied, to five, highly unsatisfied (Duc, 2008).

Group discussions were conducted with separate groups of men and women. Women farmers wanted the group discussion to be conducted separately so that they could openly discuss the issue without men around. The size of the group was 26 (for men) and 22 (for women). The respondents for group discussions were selected to represent farmers from each ward of the watershed, farmers who were members of cooperatives, and farmers who had attained trainings on cash cropping and Integrated Pest Management (IPM). The number of participation in the group discussions was relatively large because most farmers demanded to be part of the discussions and it would have been inappropriate to prevent them from participating. Due to active participation of respondents, a discussion normally lasted for three to four hours. To help overcome the challenge of coordination and information capture from the group discussions, the two trained enumerators were also taking notes. The capture of information was also enhanced by the rule that one person speaks at a time. This rule was agreed in the beginning among the participants. The discussions with farmers were designed to elicit their views on the extension services, the use of fertilizers and the fertilizer policy which was explained briefly prior to the group discussions. The information from these group discussions was analysed in order to confirm and compare the data that had been collected from individual interviews.

A one-day workshop with 16 related stakeholders was held in Kathmandu on 2 August 2009. It was organized with key persons from the Ministry of Agriculture and Cooperatives (MoAC), the NARC and the World Wide Fund for Nature (WWF), and included local-level NGO representatives, extension workers, academics (professors from Kathmandu University who had been involved in research on soil fertility management, water, and environmental pollution), and local farmers from the Ansikhola watershed. The main purpose of the workshop was to obtain broader information and a better understanding of policy issues. In particular it was aimed at understanding the origins of, and changes to, fertilizer policies. Each of the participant stakeholders was requested to present his or her perceptions of and understanding of the issues discussed. The key representative from the MoAC gave an overview of the government's fertilizer policy and the subsidy schemes. Local farmers participating in the workshop shared their experiences regarding the supply of fertilizers and their quality.

Primary and secondary data on status of fertilizer use (as stated in fertilizer policy documents), and information on soil fertility management and the extension services were collected from the Fertilizer Unit, the Monitoring and Evaluation Division and the Agriculture Extension unit of MoAC.

\subsection{Soil Sampling and Analysis}

Seven sites were selected from within the Ansikhola watershed; each site included adjacent plots with a history of traditional rather than intensified cropping. This allowed for a paired comparison of soils from contrasting plots to study the effects of intensification. The intensified plots had a history of more than 20 years of intensive cultivation, with high inputs of fertilizer and a rotation of three crops per year. The traditional plots had a history of lower nitrogen inputs and only two crops per year. Each pair of adjacent traditional and intensified plots was regarded as one site. From each plot, four replicate soil samples were taken from random positions. Since fertilizer application is concentrated mostly at 0 to $15 \mathrm{~cm}$, which is the ploughing depth and also the normal depth for root growth, soil samples were taken from this depth so that the effect of fertilization on the soil could be detected. All four replicate soil samples (each replicate contained around $1 \mathrm{~kg}$ of soil) were spread separately 
onto a large clean plastic sheet. Clods were thoroughly broken to create a uniform mix and sieved (using a $5 \mathrm{~mm}$ sieve rack) to remove plant residue and coarse materials. Around $500 \mathrm{gm}$ of each replicate soil sample from each plot was then placed in separate labelled plastic bags and stored at a field moisture temperature of $4^{\circ} \mathrm{C}$ until used. The soil $\mathrm{pH}$ was measured in a suspension of soil in $0.01 \mathrm{M} \mathrm{CaCl}_{2}$.

\subsection{Data Analysis}

Qualitative analysis of information from workshop and group discussions was used throughout the study. Descriptive statistics were used to analyze the quantitative data and were presented in percentages in figures and tables. A paired $t$-test using SPSS (version 16.0) was used to analyze differences in soil $\mathrm{pH}$ at the $p<0.05$ level of significance.

\section{Results and Discussions}

\subsection{Genesis and Development of Fertilizer Policy}

\subsubsection{Phase without Subsidy (from 1952 to 1972)}

The workshop and the literature review suggested that the use of chemical fertilizers started during the 1950s as a result of the activities of private traders from India, although the amounts used were very low (Shrestha, 2010). India was the only country from which fertilizer was imported. From 1962 to 1965, National Trading Limited (a government owned company) imported fertilizers from Russia and China. The workshop and secondary data confirmed that the import and distribution of fertilizers was formalized with the establishment of the AIC in 1966, under the Ministry of Agriculture. The AIC was a public-sector enterprise and started importing fertilizers, not only from India, but also from the wider international market (Shrestha, 2010; Thapa, 2006). The import points of fertilizers were the border cities in the terai region. During the workshop, the participant from MoAC stated that at this time farmers had to pay the costs of importing the fertilizers themselves. The cost would vary, depending on whether they resided in the terai or the hill regions. Hill farmers had to pay more than farmers in terai since they had to pay the additional cost of transportation from the border cities in the terai to the hill areas (Shrestha, 2010). As a result, farmers in the hills found it difficult to afford fertilizers.

\subsubsection{The Introduction of a Subsidy (from 1973/74 to 1996/97)}

With the aim of increasing food production, the government introduced a subsidy on fertilizer in 1973/74 (APP, 1995). The main purpose of the subsidy was to encourage an increase in chemical fertilizer use by farmers. The subsidy policy included both a price subsidy on the fertilizer and a transport subsidy for hill and mid-hill districts (APP, 1995). The price subsidy applied throughout the country, while the transport subsidy only applied to farmers residing in hill and mid-hill regions. The transport subsidy applied to the transportation costs incurred while transporting fertilizers from terai region to the hills. However during this period, the farmers that mainly benefited were those with personal networks such as those with direct contact with MoAC. More than $80 \%$ of the subsidized fertilizer was sold only in Kathmandu valley (Ghimire, 2009).

\subsubsection{The Deregulation of the Fertilizer Trade (from 1997/98 to 2007/2008)}

With the growing demand for fertilizer within the country and, at the same time, a rise in fertilizer price on the international market, the subsidy became a huge financial burden for the Nepalese government. The AIC's deficit rose to 850 million rupees during the twenty-three years of subsidy period (Shrestha, 2010), and the AIC was unable to meet the demand for fertilizer. During this time, farmers had to queue up at the AIC's retail outlets, but were still unable to buy sufficient quantities of fertilizer (NARMA, 2006). As a result, the government started to deregulate the fertilizer trade in November 1997, removing the subsidy on fertilizers such as Diammonium Phosphate (DAP) and Muriate of Potash (MoP) at the same time; the subsidy for urea was also phased out later. After November 1999 all subsidies were completely removed. After deregulation, MoAC began to involve the private sector in the fertilizer trade. The AIC was dissolved and in its place two companies were formed: the Agriculture Input Company Limited (AICL), responsible for the fertilizer business, and the National Seed Company Limited (NSCL), responsible for crop seed business. These changes were made in terms of the Company Act of 1996 (Shrestha, 2010). Deregulation removed the AIC's monopoly in the fertilizer trade and provided opportunities for the private sector to participate.

\subsubsection{The Current Policy on Fertilizer Subsidies (from 2009 to the present)}

Discussions with stakeholders suggested that the deregulation policy which remained in place until early 2009, largely failed to improve the supply and quality control of fertilizer (NARMA, 2006). Due to the excessive rise in the price of fertilizers, farmers could not afford to buy fertilizers of good quality. They were forced to use fertilizers of unknown quality that were available on the free market at lower prices. Thus, the government 
finally approved the policy of subsidizing chemical fertilizers on March 25, 2009. The subsidy scheme targets small and marginal farmers. The MoAC decided to offer subsidized fertilizers for farmers with up to 4 ha in terai and up to 0.75 ha of land in the hill region. Table 1 summarizes the different phases of subsidy schemes for fertilizer.

Table 1. Summary of changes in subsidy scheme

\begin{tabular}{|c|c|c|c|}
\hline Key feature & Period & Responsible agency & Challenges \\
\hline $\begin{array}{l}\text { Phase without } \\
\text { subsidy }\end{array}$ & $\begin{array}{l}1952 \text { to } \\
1972\end{array}$ & $\begin{array}{l}\text {-National Trading } \\
\text { Limited } \\
\text {-Agriculture Input } \\
\text { Corporation (AIC) }\end{array}$ & $\begin{array}{l}\text { Fertilizer cost was not uniform } \\
\text { for the farmers all over the } \\
\text { country. }\end{array}$ \\
\hline Phase with subsidy & $\begin{array}{l}1973 / 74 \\
\text { to } \\
1996 / 97\end{array}$ & -AIC & $\begin{array}{l}\text { Uneven distribution of fertilizer; } \\
\text { supplies are plentiful in } \\
\text { Kathmandu valley. }\end{array}$ \\
\hline $\begin{array}{l}\text { Phase with } \\
\text { deregulation of } \\
\text { fertilizer trade }\end{array}$ & $\begin{array}{l}1997 / 98 \\
\quad \text { to } \\
2007 / 08\end{array}$ & $\begin{array}{l}\text {-Agriculture Input } \\
\text { Company Limited } \\
\text { (AICL) }\end{array}$ & $\begin{array}{l}\text { Government failed to increase } \\
\text { private sector involvement } \\
\text { in import and } \\
\text { distribution of fertilizers. }\end{array}$ \\
\hline \multirow{3}{*}{$\begin{array}{l}\text { Phase with current } \\
\text { subsidy on fertilizer }\end{array}$} & & -and private traders & \\
\hline & $\begin{array}{l}2009 \text { to } \\
\text { present }\end{array}$ & -AICL & $\begin{array}{l}\text { Subsidized fertilizer covers only } \\
\text { one-fourth of the country's total } \\
\text { fertilizer requirement. }\end{array}$ \\
\hline & & -and private traders & \\
\hline
\end{tabular}

\subsection{Imported Fertilizers}

There are four main sources of fertilizers imports, namely, fertilizer imports from grants, from official AIC imports, from official imports by the private sector and from unofficial imports by the private sector. Fertilizer grant-providing countries were not the same countries where official imports were made from. During the 1990s, a number of governments (Germany, Canada, Japan and Finland) provided aid to Nepal in the form of fertilizer grants. Around 20,000 tons of fertilizer has been imported annually in 1990s. However, the grant from Germany and Finland stopped in 1991/1992 and from Canada in 1992/1993. The MoAC received the fertilizers obtained through grant-aid and the AIC had the responsibility of selling them at the existing market rate. Until the system was liberalized in 1997, the AIC had the primary responsibility for the import and distribution of fertilizers. During and after the period of liberalization, there was a decline in the import and sale of fertilizers by the AIC. This decline was due to the participation of the private sector in the importation and distribution of fertilizers because they officially imported mainly urea. Imported fertilizer mostly came from China, USA, the Gulf countries, Eastern Europe and Bangladesh. It was imported to Singapore for trans-shipment to Calcutta in India. From Calcutta, the fertilizers were transported to Raxaul (on the border to Nepal) and then to Birgunj (one of the border cities in Nepal) by train or truck. From Birgunj, fertilizers were supplied to other border towns in the terai area (Figure 1).

There were also unofficial imports of fertilizers through the open borders with India. It is estimated three times as much fertilizer was imported in this way, as compared to official imports (Thapa, 2006). It was revealed during the workshop with the representatives from MoAC that traders or depots would sell their fertilizer directly across the open border to Nepal and this trade was not recorded. It was also revealed that the fertilizer sold to private traders in Nepal from India included the original cost of fertilizer, the cost of fertilizer collection and any payments made en route to Nepal. Some of the private traders, who were unofficial importers, would adulterate the fertilizer by mixing in powder that looked like fertilizer. They would use a popular brand name or the name of the AICL, cheating the farmers in this way. Even though they were unofficial, these private traders 
provided the bulk of the fertilizer needed by farmers (see Table 2). During 2000/01, the total amount of fertilizer consumed by households was 428,373 tons with $66 \%$ of it was supplied through unofficial imports, and this proportion increased over time. By 2005/06, the share of unofficial imports in the total consumption of 423,887 tons of fertilizer had reached $71.6 \%$ (Thapa, 2006).

Table 2. Sources and amount of fertilizer imports

\begin{tabular}{llc}
\hline Fertilizer import sources & \multicolumn{1}{l}{ Amount of fertilizer imports (MT) } \\
\hline & $2000 / 01$ & $2005 / 06$ \\
AICL import & 45,220 & \\
Private traders & 101,145 & 120,536 (AICL+private traders) \\
Unofficial import private traders & 282,008 & 303,351 \\
\hline
\end{tabular}

Source: Thapa, 2006.

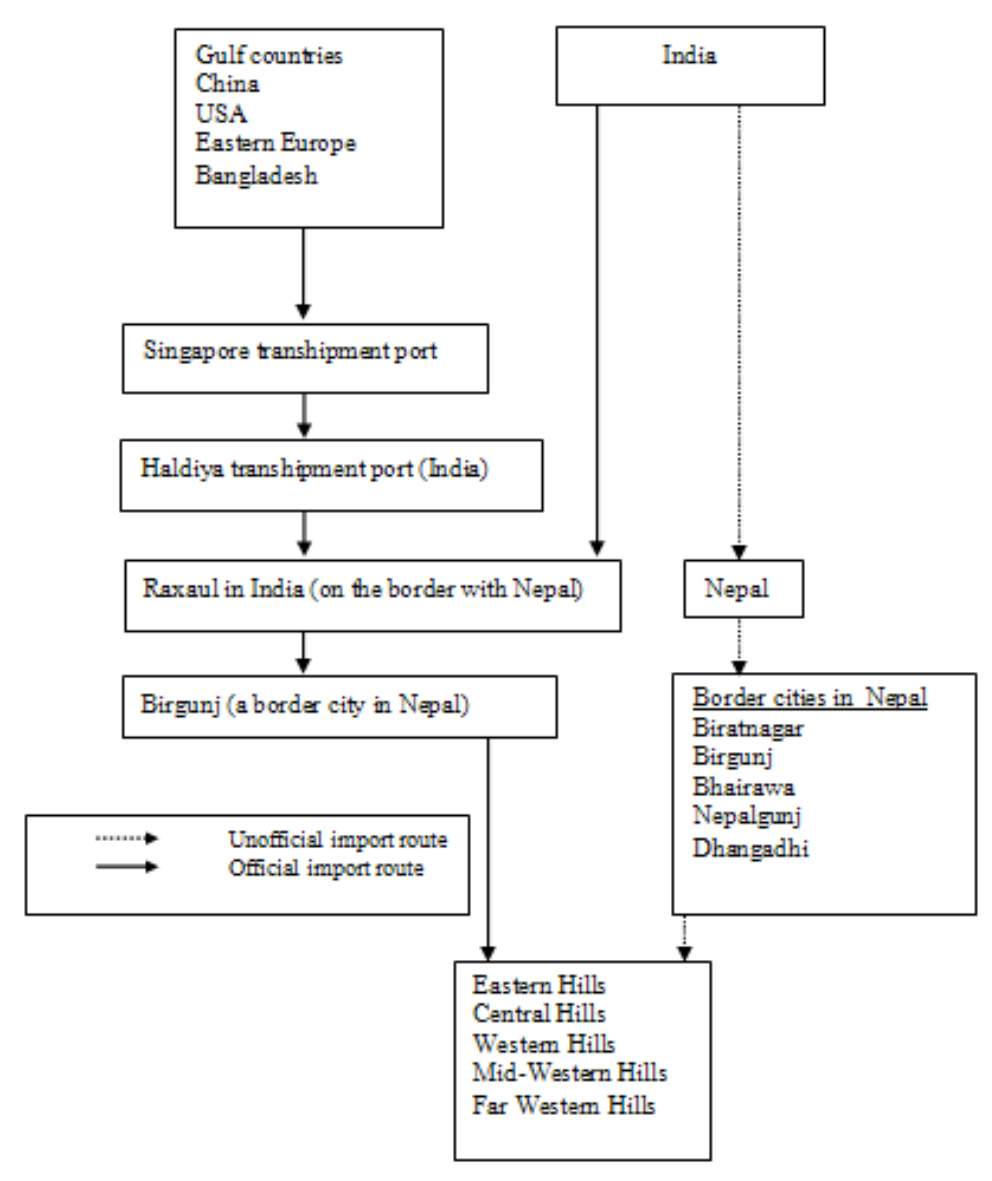

Figure 1. Sources and transport routes of fertilizer imports to Nepal

\subsection{The Extension System and its Performance in Relation to Fertilizer Input}

\subsubsection{The Evolution of Agriculture Extension Services in Nepal}

A review of the agriculture extension service suggested that in the short span of 60 years, public sector extension services faced frequent organizational changes. The extension service was instituted in 1951 with financial and technical support from India and the United States ( $\mathrm{KC}$ et al., 2003). External assistance from the United States helped in the establishment of the Tribhuvan Village Development Department (TVDD), leading, in 1952, to systematic initiatives in the agricultural sector (Blackie \& Sadeque, 2000). TVDD introduced the Block 
Development Approach in extension (KC et al., 2003). This approach was later retained by the Department of Agriculture (DOA) after it was established in 1955. The extension division under the DOA was in contact with zonal extension offices. The DOA was later reorganized a number of times. At present the extension services are operated through two departments, the Department of Agriculture and the Department of Livestock Services, which falls under the MoAC.

A number of approaches to extension services have been adopted to date (Manandhar, 2007; KC et al., 2003; Blaikie \& Sadeque, 2000). These include the following:

(1) In traditional approaches, junior technicians (JTs) and junior technical assistants (JTAs) are deployed at the local level to select innovative farmers and promote the extension of agricultural technology by organizing training sessions and exhibitions with these farmers (Blaikie \& Sadeque, 2000). This was introduced in the 1970s by the Village Development Centers.

(2) The Training and Visit Approach (T \& V) was introduced in 1975. The main aim was for extension workers to visit farmlands regularly and deliver a message to farmers (KC et al., 2003). A sub-district level network of service centres was established to communicate with farmers at fortnightly intervals. This approach was introduced by the World Bank-funded Narayani Zone Irrigation Development Project in three districts in the terai region ( $\mathrm{KC}$ et al., 2003). It was then introduced in other World Bank-funded projects, such as the Agricultural Extension and Research Project, the Hill Food Production Project and the Agricultural Extension Project; the Asian Development Bank (ADB)-and UK Department for International Development (DFID)-funded projects.

(3) In the "Tuki approach", Tuki represents an active extension worker from the rural area for agriculture and development of that area (Tuki literally means a typical kerosene lamp in Nepalese). This approach was introduced in 1977. These workers were supposed to act as a source of information as well as commissioning agents for the purchase of agricultural inputs (Blaikie \& Sadeque, 2000). They did not have a specified salary and relied on the commission they got from the inputs they sold on behalf of AICL.

(4) The group approach was introduced during 1990s. In the group approach, farmers' groups consisted of according to the main commodity which they grew (Manandhar, 2007). The main purpose of the group approach was to reduce the gap between the service providers and the intended beneficiaries.

(5) The farmers' field school is a group-based experimental learning activity which involves simple experiments at the field level, regular field observations, and group analysis (Manandhar, 2007). Recent extension services that use this approach in Nepal are the IPM and the Farmers Field Schools (FFS).

\subsubsection{The Role of the Extension System in Providing Agricultural Related Information}

Farmers indicated that agricultural extension through radio and television was becoming increasingly effective as a way of reaching farmers. Out of a total of 310 households, 304 households either have a radio or a television or both. Most of the farmers who responded to the survey $(51 \%)$ listened to or watched agricultural programs that were delivered via radio or television. These included programmes on high-yielding crop varieties, pest and disease control, use of organic and chemical fertilizers, soil fertility management, etc. However, almost half ( $47 \%$ ) of the responding farmers did not follow these programmes although they knew about them, while a few farmers $(2 \%)$ were not aware of the programs. However, the variation among the farmers in terms of access to radio and television affected their ability to receive information. The responding farmers who were not aware of extension programmes did not have access to information via radio and television. Access to information about extension services seemed to be related to the economic status of the farmers. The study by Dahal et al. (2009) in the same watershed categorized farmers into three major wealth groups: large, medium and small farmers. This was based on criteria (such as land, property, profession, education, cattle and agricultural production) which were used by local farmers. Small farmers were those whose agricultural production could only be sustained for less than six months-meaning that these farmers were not able to buy seeds and fertilizer in time for cultivatation, and they could not afford radios and televisions.

Most of the farmers (96\%) reported during their individual interviews that they had not been previously assisted or visited by extension workers. Only a few farmers $(4 \%)$ reported extension visits. Discussions with the farmers and a review of the literature indicated that political interference, low institutional capacity, and the lack of a group approach were the main reasons for the limited success of the various attempts to extend agricultural services and advice. However, the present study showed that the extension services provided by the government via the media could be successful. However, at the field level the extension service did not work, with the exception of new approaches such as the FFS approach. Some of the male farmers who are educated and had 
experience in the group approach suggested that FFS was succeeding in some other districts of Nepal. According to them, group approaches such as the FFS were regarded as participatory and gender inclusive.

\subsubsection{Role of the Extension System in Fertilizer Distribution}

One of the extension policies includes the provision of inputs and technical services such as soil testing, supply of fertilizer, access to credit and the provision of plant protection services in an integrated manner by means of agricultural services at the sub-district level (Thapa \& Rosegrant, 1995). The AICL operates its extension services for fertilizers through retail outlets and cooperatives. However, the private sector and some NGOs also support agricultural extension activities. Farmers reported the delivery of extension services, particularly regarding the use of fertilizers and new higher yielding crop varieties, is contributing to an increase in household incomes in the study area and in similar mid-hill watersheds in Nepal. The intensification of agriculture in the study area has seen an increase in the number of crops planted and the increased use of fertilizers. Farmers have introduced spring rice and winter potatoes and vegetables in a shift from the traditional two-crop system to a three-crop system (Raut et al., 2011). According to the study conducted by Dahal et al. (2009) in the same study area, farmers perceived an improvement in their socio-economic condition due to adoption of intensified agriculture. The cultivation of potatoes, tomatoes and other vegetables is more profitable if one can invest in the necessary inorganic fertilizers and pesticides. Farmers could now save money by selling their surplus production in the study area. Other studies have also found that an improvement in household incomes was due to the intensification of agriculture in other mid-hill regions (Tiwari et al., 2008; Brown \& Shrestha, 2000).

The liberalization of the fertilizer sector in 1997 resulted in a number of policy changes, such as the phasing out of price subsidies, the development of a new fertilizer policy and controls, and the upgrading of fertilizer by quality testing. These policy and institutional reforms were designed to encourage increased private sector participation to meet domestic needs. The main aims of both the Fertilizer Control Order (1997) and National Fertilizer Policy (2002) were to encourage the involvement of private and cooperative firms in the import and distribution of fertilizer, thereby enhancing farmers' access to and use of fertilizer. The distribution of fertilizer through the AIC is mainly directed at the less developed regions where distribution networks are poor, and where the private sector has limited reach. The private sector has concentrated on improving distribution networks in areas that are more developed, where there is a larger market for fertilizer (ACI, 2003). The development of a National Fertilizer Policy (NFP) involved a number of stakeholders. These included policy makers, fertilizer producers, fertilizer importers and distributors, traders, researchers, agricultural extension officers and farmers. The policy-makers have also considered the importance of microbial and organic fertilizers for the development of an integrated system for the management of plant nutrients. However, this has yet to be implemented.

In terms of current policy on fertilizer subsidies, subsidized fertilizers are distributed through the offices of the AICL and the cooperatives (Shrestha, 2010). However, the government's inadequate distribution network is likely to hamper distribution. The government-owned AICL has only 40 offices in 39 districts - out of a total of 75 districts (Ghimire, 2009). For the remainder of the districts, distribution will have to be done through cooperative firms. However, in the past (during the fertilizer subsidy regime), these cooperatives did not pay for the fertilizer that they received from the government (Ghimire, 2009). As a result, these cooperatives were unable to obtain more fertilizer from the government, creating situations where the farmers had to go to AICL's the district headquarters to buy subsidized fertilizer (information obtained from personal communication with MoAC official). In the current subsidy policy, only 100, 000 metric tons of subsidized fertilizer is allocated annually, which is less than one-fourth of the total requirement (Shrestha, 2010). Farmers also have to provide valid proof of land ownership to obtain the subsidized fertilizer creating problems for some small farmers who are tenant even though the subsidy scheme is intended also for such farmers.

The monitoring and dissemination of the information plays a key role in helping to ensure that the strategies and programs undertaken meet targets set by the NFP. The issue of monitoring was raised during the group discussion. According to the farmers, important areas to be monitored include fertilizer availability and its quality at the local level. In the farmers' experience, the supply is usually much less than the demand. In few cases, where there was a surplus of fertilizer in local retail shops, shopkeepers would hide the fertilizer and sell it later at a higher price. Farmers also expressed their concern at the instability of fertilizer prices among retailers at the local level, particularly when fertilizer was in short supply. The farmers also mentioned that the fertilizer monitoring system was not effective and that information was not disseminated to the key stakeholders, such as farmers, traders, line agencies and NGOs. The challenge of ensuring the smooth distribution of subsidized fertilizers needs to be addressed by developing a workable policy and taking action on the ground through improved extension services. 


\subsection{Farmer's Action and Soil Acidification}

A farmer's choice of fertilizer is determined by the price of the fertilizer and the choice of crop grown. When the prices of fertilizers are compared, one finds that urea costs less than DAP and MoP. In India, the price of urea and DAP is even lower, almost half the price in Nepal. Because of the lower price, the illegal import of fertilizers (especially urea) from India by private traders has been increasing. Due to the low price and the readily available urea, most farmers prefer to use nitrogenous fertilizers (such as urea) rather than any other fertilizers: one finds a decreasing use of farmyard manure (Raut et al., 2011). Private traders provide fertilizers on time and if needed they also extend loans to the farmers. Thus farmers often buy fertilizers from privately owned chemical fertilizer stores (Raut et al., 2011). In many instances, according to farmers, these stores lack information about the fertilizers. The farmers may also be uninformed regarding their use. Thus as a result of poor extension services there is a lack of awareness and a disproportionate use of Nitrogen-Phosphorus-Potassium (NPK) fertilizers. On the other hand, many farmers still believe that high-yielding crop varieties require the use of greater amounts of chemical fertilizer if production is to be increased. The main threat associated with the use of nitrogenous fertilizer (mainly urea) is that it may cause nutrient imbalances in the soil. Soil bacteria oxidize ammonium-based fertilizers to $\mathrm{NO}_{3}{ }^{-}$and $\mathrm{H}^{+}$, thus causing soil acidification.

A laboratory analysis of the soils revealed that the $\mathrm{pH}$ has been significantly lowered as a result of intensive cultivation $(p<0.05)$. The average $\mathrm{pH}$ of the soil under intensified cultivation was 4.49 . In contrast, the average $\mathrm{pH}$ was 5.17 in the traditional agricultural system (Figure 2). Comparisons of plots under intensified cultivation and adjacent plots where more traditional low-input farming practices are used show convincingly that intensification has substantially lowered the $\mathrm{pH}$ of the soil $(p<0.05)$. Brown (1997) analyzed soil $\mathrm{pH}$ in 1994 from less intensively farmed sites with a cropping rotation of less than two crops per year in Jhikhu Khola watershed, which is adjacent to areas with similar biophysical and socioeconomic conditions to the present study area. Brown (1997) reported in 1994 that the soil pH was found to be 5 for the less intensively farmed soils, which, when compared with the $\mathrm{pH}$ of soil under intensive cultivation, was higher by 0.5 . This supports the findings of this study that intensification has increased the soil acidity. Guo et al. (2010) studied soil acidification in Chinese croplands and highlighted the direct and indirect effects of excessive amounts of nitrogen $(\mathrm{N})$ as the main driver of acidification, in combination with enhanced extraction of base cations (through crop uptake and removal with harvests). This implies that the most important factor leading to increased soil acidity in our study area was the growing of three crops annually and the excessive use of nitrogenous fertilizer $\left(320 \mathrm{~kg} \mathrm{~h}^{-1}\right.$ only for potato cultivation) in most of the intensified plots. The incubation study showed that the intensified agricultural system led to a significantly higher $\mathrm{N}_{2} \mathrm{O} / \mathrm{N}_{2} \mathrm{O}+\mathrm{N}_{2}$ product ratio $(p<0.01)$, meaning that decreasing soil $\mathrm{pH}$ increases the product ratio of denitrification (Raut et al., 2012), indicating that soil acidification increases the propensity of the soil to emit $\mathrm{N}_{2} \mathrm{O}$ gas.

Soil acidification could be one of the reasons contributing to a decrease in crop yield. The farmers reported decreases in the yield of cereal crops per hectare. The average yield of maize decreased from $1.98 \mathrm{t} \mathrm{ha}^{-1}$ in 1999 to $1.56 \mathrm{t} \mathrm{ha}^{-1}$ in 2009. The yield of rice, on average, decreased by $1.3 \%$ from 1999 to 2009 (Raut et al., 2011). Fertilizer application is one of the most important determinants of increased food production. However, in the long run it may not be a sustainable way of increasing food production, unless fertilizer is used more efficiently and soil acidity is reduced. One of the methods of reducing soil acidity is by liming the soil. According to farmers, however, lime is not readily available and even if it were, farmers would not be able to afford it because of its high price. 


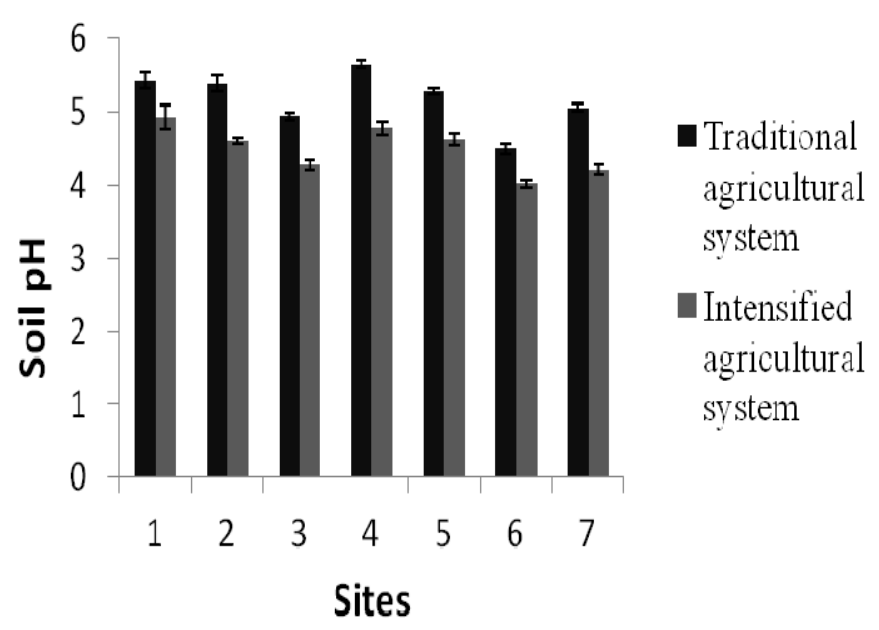

Figure 2. Soil pH measured in traditional and intensified agricultural systems

\subsection{Farmers' Perceptions of Fertilizer Policy and Training}

The descriptive analysis of the results showed that only $12 \%$ of the respondents were aware of the reintroduction of fertilizer subsidies. This indicates almost $88 \%$ of farmers were not aware of the current changes in the fertilizer policy, possibly as a result of ineffective extension services. When this group (the $12 \%$ who were aware of the reintroduction of subsidies) was asked about their level of satisfaction, $44 \%$ were satisfied, $14 \%$ were highly satisfied, $28 \%$ were neutral and $14 \%$ were dissatisfied (Figure 3 ). Those farmers who were satisfied with the subsidy policy believed that the subsidized rate of fertilizer would lower their investment on fertilizers. However, the reason for farmers showing dissatisfaction on the subsidy policy was due to uneven distribution of fertilizer among the farmers. The results showed that $21 \%$ and $7 \%$ of the farmers had attended training sessions on cash crops and IPM respectively. Most farmers who had attended training sessions on cash crops (68\%) and on IPM (82\%) were satisfied, and there were none who were dissatisfied (Figure 3). This suggests that a farmer-friendly policy need to be supplemented by extension approaches such as IPM, and by training and strategies for collective action.

These levels of satisfaction were crosschecked during the group discussion, where farmers confirmed that they were satisfied with the training sessions on cash crops and IPM. The farmers had not only participated in the training sessions on IPM and off-season vegetable production, but were also participating in exposure trips and observation visits to farmers' field schools and commercial farm stations in other parts of the country, organized by District Agriculture Development Office (DADO) and by NGOs. This raised confidence levels and enhanced technical skills among the farmers. Farmers were grateful that the Japan International Cooperation Agency (JICA) had initiated commercial vegetable farming in the watershed and that the Centre for Environmental and Agricultural Policy Research, Extension and Development (CEAPRED) had established one of the four collection centres in the watershed in order to facilitate the collection and marketing of vegetables. The collection centre was constructed with the farmers' participation and with contributions from VDC. The farmers said that the services provided by the NGOs were more efficient than those provided by Government Organizations (GOs) (Raut et al., 2011).

The discussants from the women's group expressed their willingness to participate if offered training in the application and quality checking of chemical fertilizers. In their experience, fertilizers bought from retail shops were sometimes different in colour and texture, and seemed less effective. Mostly it is the women who are involved in carrying organic manure to the fields. They showed a common interest to participate in the training of the application of fertilizer so that they could judge the amount of both chemical and organic fertilizer applied. Women farmers also said that training on cash cropping in the past had helped them to be a part of decision-making activities and had led them to play a more active role in society. Social norms tended to confine them to the household and limited their outdoor participation, so active roles in society was important to them.

Farmers reported during the group discussion that whenever they had problems related to their crops (such as pest problems, or wanting soil $\mathrm{pH}$ to be tested) they had to ask the DADO for assistance. In many instances however, they failed to receive any assistance. Farmers reported during the workshop that they brought soil samples directly to NARC, but either it took a long time (about six months) to obtain the results, or in most of 
the cases, their samples were just ignored. However, during the group discussion and in the workshop, farmers acknowledged the contribution of organizations such as JICA and CEAPRED in changing a food deficit situation to one where intensified farming played an important role.

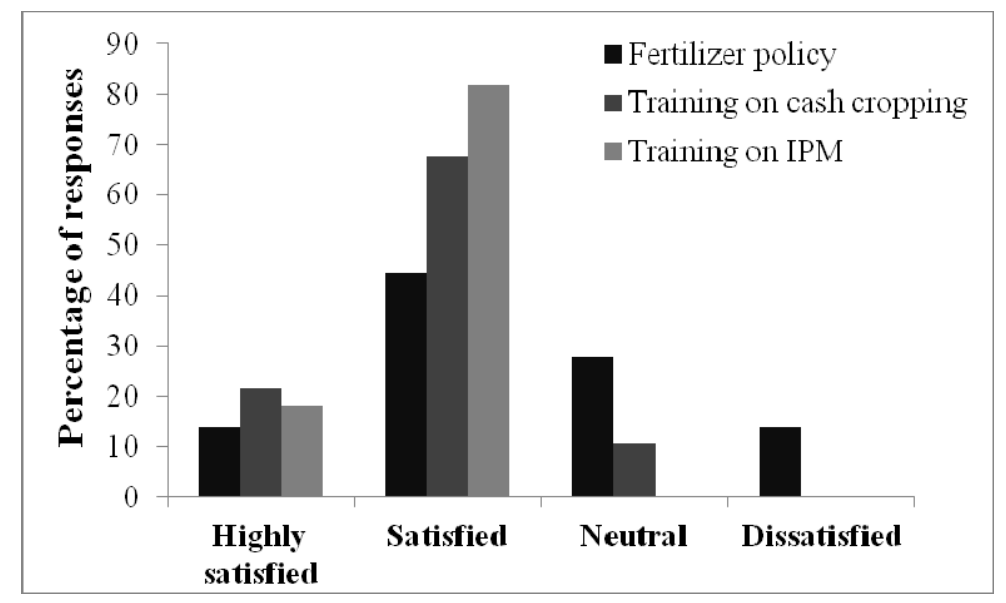

Figure 3. Farmers' satisfaction with fertilizer policy and trainings

This includes the response of $11.6 \%$ of farmers who were aware of fertilizer policy.

\section{Conclusion and Policy Implications}

In spite of decades of government policies prioritizing fertilizer as the leading driver of increased agricultural output, Nepal has yet to see the benefit in terms of higher yields. The development of effective and convenient policy with regard to the distribution and use of fertilizer has always been a challenge for the government. The paper has analyzed the genesis and development of this policy, and provided insights and feedback from the farmers who are the prospective beneficiaries of policy changes. The paper reaches the following conclusions:

(1) Although there have been changes in fertilizer subsidy schemes several times with the current subsidy policy announcements, the importation and distribution of fertilizer to farmers remains a challenge.

(2) Farmers were often unaware of policy changes with regard to fertilizer, of those who were aware, most were satisfied with these changes.

(3) Although the government extension system that operates through the media is working, most farmers regarded the extension services provided by NGOs at the field level as more efficient. Extension services provided by GOs were hampered by low institutional capacity and the inability of these services to operate effectively in the field.

(4) Increases in soil acidity could be attributed to the increased use of nitrogenous fertilizers, and declining or stagnant cereal yields could make it difficult to meet the future demand for food. Further research is needed if the desired yields are to be obtained with minimal impact on the sustainability of production and the environment.

The agriculture development of Nepal should be addressed with a three-tier approach: (1) Farmer access to efficient distribution of quality fertilizers must be ensured. (2) Extension services must be strengthened and should focus on the integrated management of plant nutrients. (3) Since a large amount of fertilizer comes from unofficial sources - three times that of official imports come from agents such as private traders- the involvement of the private sector could develop a sense of responsibility among the private traders and increase their participation in the importation and distribution of fertilizer. The establishment of a separate unit in the MoAC for the private sector would encourage this sector to feel an increased sense of ownership of this unit and would increase their role in the importing of fertilizer. The government could explore the possibility of entering into joint ventures with public-private sector entities in neighbouring countries to increase fertilizer production and ensure a sufficient supply fertilizer.

The reintroduction of a subsidy policy raises the complex issue of the beneficiary. The scheme should target the small and marginal farmers who should benefit most from the subsidy. The appointed "Fertilizer Supply and Distribution Management Committee" in each district should ensure that the targeted groups are the ones who benefit. 
Based on the perceptions of farmers with regard to extension services, it would seem that access to these services is necessary if the benefits of modern farming techniques are to be demonstrated and their adoption encouraged. Therefore, the effective provision of extension services is essential.

The NFP (2002) addressed the overall issue of soil management. However, appropriate institutions are needed to implement the policy. In the NFP (2002) and APP (1995), there is no formal mention of the need for agricultural liming in the treatment of acidic soil. The importance of the liming acidic soil has, however, been broadcast through agricultural programmes on radio and television. Since agricultural extension services provide mechanisms for sharing information with farmers, there is a need for these services to be responsive and relevant. One of the ways to achieve this is to increase the institutional capacity of subject specialists and to introduce more interdisciplinary ways of involving farmers, research scientists and extension officers. An extension system that is capable of responding to farmers' needs and able to advise on the application of fertilizer according to plant needs is clearly required.

\section{Acknowledgements}

This research was funded by the Norwegian Council for Higher Education's Program for Development Research and Education (NUFU) through the project, 'Education Research and Training for Sustainable Management of Natural Resources in Himalayan Watersheds', IOF/UMB project (PRO 2007/10109) and and RNE funded project 'Conservation of Biodiversity and Sustainable Use of Natural Resources: Capacity Building for Interdisciplinary Research and Applications (IND 3025 05/085)'.

\section{References}

ACI. (2003). Nepal fertilizer use baseline study. Report of Agrifood Consulting International. Oxford Policy Management, Kathmandu, Nepal.

APP. (1995). Agricultural Perspective Plan (Final Report). National Planning Commission, Agricultural Projects Service Centre, Kathmandu, Nepal.

Blaikie, P. M., \& Sadeque, S. Z. (2000). Policy in high places: Environment and development in the Himalayan Region. International Centre for Integrated Mountain Development, Kathmandu, Nepal.

Boserup, E. (1965). The conditions of agricultural growth: The economics of agrarian change under population pressure. London: Earthscan Publications Ltd.

Brown, S. (1997). Soil fertility, nutrient dynamics, and socio-economic interactions in the Middle Mountains of Nepal. PhD. Thesis, Interdisciplinary Studies in Resource Management Science. University of British Columbia, Vancouver, BC.

Brown, S., \& Shrestha, B. (2000). Market-Driven Land-Use Dynamics in the Middle Mountains of Nepal, Journal of Environmental Management, 59, 217-225. http://dx.doi.org/10.1006/jema.2000.0355

Brown, S., \& Kennedy. G. (2005). A case study of cash cropping in Nepal: Poverty alleviation or inequity? Agriculture and Human Values, 22, 105-116. http://dx.doi.org/10.1007/s10460-004-7234-z

CIP. (2010). Nepal Agriculture and food security, Country Investment plan.

Dahal, B. M., Nyborg, I., Sitaula, B. K., \& Bajracharya, R. (2009). Agricultural Intensification: Food Insecurity to Income Security in a Mid-Hill Watershed of Nepal. International Journal of Agricultural Sustainability, 7(4), 249-260. http://dx.doi.org/10.3763/ijas.2009.0436

Duc, N. M. (2008). Farmers' satisfaction with aquaculture-A logistic model in Vietnam. Ecological Economics, 68, 525-531. http://dx.doi.org/10.1016/j.ecolecon.2008.05.009

FAO. (2011). Current world fertilizer trends and outlook to 2015. Food and Agriculture Organization of the United Nations, Rome, Italy.

Foresight. (2011). The future of food and farming: Challenges and choices for global sustainability. Final project report. The Government Office for Science, London.

Ghimire, P. (2009). Distribution of subsidized fertilizer to farmers big challenge. Republica.

Gulati, A., \& Sharma, A. (1995). Subsidy syndrome in Indian Agriculture. Economic and Political Weekly 30: A93-A102.

Guo, J. H., Zhang, Y., Shen, J. L., Han, W. X., \& Zhang, W. F. (2010). Significant acidification in major Chinese croplands. Science, 327, 1008-1010. http://dx.doi.org/10.1126/science.1182570

HMGN. (1997). Fertilizer Control Order. His Majesty's Government of Nepal. 
KC, G. K., Pradhan, D., Upadhyay, B. P., \& Upadhyay, S. (2003). Sharing countries agricultural extension experiences, challenges and opportunities. Regional workshop on operationalizing agriculture extension reform in south Asia, New Delhi, India.

Manandhar, D. N. (2007). Agricultural extension education, Dangol Printers, Kathmandu, Nepal.

Matsumoto, T., \& Yamano, T. (2011). The impacts of fertilizer credit on crop production and income in Ethiopia: In: Emerging Development of Agriculture in East Africa: Markets, Soil and Innovations, T. Yamano et al. Frank (Eds.)

MoAC. (2005). Selected indicators of Nepalese agriculture and population. Ministry of Agriculture and Cooperatives, Kathmandu, Nepal.

Murgai, R., Ali, M., \& Byerlee, D. (2001). Productivity growth and sustainability in post-Green Revolution agriculture: the case of the Indian and Pakistan Punjabs. World Bank Research Observer, 16, 199-218. http://dx.doi.org/10.1093/wbro/16.2.199

NARC. (2010). Nepal Agricultural Research Council. NARC's strategic vision for agricultural research 2011-2030. Retrived from http://www.narc.org.np/narc_vision/NARC_vision.pdf

NARMA. (2006). Impact of fertilizer deregulation policy. Prepared by NARMA Consultancy Pvt. Ltd. Kathmandu, for the Ministry of Agriculture and Cooperatives, Kathmandu, Nepal.

NFP. (2002). National Fertilizer Policy. His Majesty's Government of Nepal. Kathmandu.

Raut, N., Sitaula, B. K., Aune, J. B., \& Bajracharya, R. M. (2011). Evolution and future direction of intensified agriculture in the central mid-hills of Nepal. International Journal of Agricultural Sustainability, 9, 537-550. http://dx.doi.org/10.1080/14735903.2011.609648

Raut, N., Dörsch, P., Sitaula, B. K., \& Bakken, L. R. (2012). Soil acidification by intensified crop production in South Asia results in higher $\mathrm{N}_{2} \mathrm{O} /\left(\mathrm{N}_{2}+\mathrm{N}_{2} \mathrm{O}\right)$ product ratio of denitrification. Soil Biology and Biochemistry, 55, 104-112. http://dx.doi.org/10.1016/j.soilbio.2012.06.011

Rosenau, P. V. (2000). The strengths and weaknesses of public-private policy partnerships. In: Public-Private Policy Partnerships, ed. P.V. Rosenau. Cambridge, Mass: MIT Press.

Samriddhi. (2011). Commercialization of agriculture in Nepal. Discussion Paper. A Samriddhi publication.

Shrestha, R. K. (2010). Fertilizer policy development in Nepal. The Journal of Agriculture and Environment, 11, 126-137.

Thapa, Y. B. (2006). Constraints and approach for improving fertilizer supply for meeting domestic demand. Economic Policy Network, Government of Nepal, Kathmandu, Nepal.

Thapa, G. B., \& Rosegrant, M. W. (1995). Projections and policy implications of food supply and demand in Nepal to the year 2020. Research Report Series, No. 30. Published by Winrock International.

Tiwari, K. R., Nyborg, I. L. P., Sitaula, B. K., \& Paudel, G. S. (2008). Analysis of the sustainability of upland farming systems in the Middle Mountains region of Nepal. International Journal of Agricultural Sustainability, 6(4), 289-306. http://dx.doi.org/10.1007/s10705-009-9289-0 